\title{
Biodeterioration of Building Materials by Cyanobacteria and Algae
}

\section{J. J. Ortega-Calvo." M. Hernandez-Marine ${ }^{h}$ \& C. Saiz-Jimenez"}

"Instituto de Recursos Naturales y Agrobiologia. CSIC. Apartado 1052, 41080 Sevilla. Spain

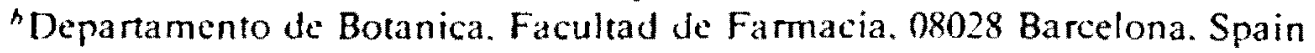

\section{ABSTRACT}

A study of the presence of cyanohacteria and algae in different building materials from Spain (Salamanca. Seville and Toledo Cathedrals) and Sweden (Lund Cathedral) and their possible relation to the stone decay was accomplished. Colonization of stone with the cyanobacterium Microcoleus vaginatus and the chlorophyte Klebsormidium flaccidum was also induced in the laboratory. In both field and laboratory samples, the microbial film. spontaneously detached, showed on its reverse side the presence of arains removed from the stone surface. thus causing mechanical deterioration on the colonized materials.

\section{INTRODUCTION}

Like all humid and illuminated substrates, monument walls support the growth of diverse organisms, whose presence is related to the natural mechanisms involved in the formation and degradation of terrestrial substrates. The colonizers of such surfaces are often atmophytic cyanobacteria and algae with characteristics closely related to the pioneer ones present in non-flooded soils (Anagnostidis et al.. 1983), and in some cases they are the same species.

The taxonomy and ecology of soil algae have been reviewed by 
Metting (1981). Starks et al. (1981) and recently by Hoffmann (1989). The presence of cyanobacteria and algae on a substrate (limestone. sandstone etc.) enable its disintegration (Starks \& Shubert. 1982). Nevertheless, the deleterious effects of the cyanobacteria and algae on building materials could not be clarified even after an extensive review of the literature by Hueck-van der Plas (1968). According to Grant (1982) the position has remained unchanged since then, and is still. now, a matter of controversy. Their aggressive action in relation to the substrate where they develop has been considered negligible by some authors, who consider important only the aesthetic damage they cause (Dukes, 1972; Paleni \& Curri, 1973: Tiano, 1986). Nevertheless, there are reports on a role of cyanobacteria and algae in the weathering of stone in nature (Pomar et al. 1975: Danin et al., 1983; Viles, 1987) as well as in monuments and sculptures (Hyvert, 1973; Giaccone et al., 1976; Danin. 1983). The present paper consists of a study of the presence of cyanobacteria and algae in different monuments, and their possible relation to the stone decay process as viewed by scanning electron microscopy.

\section{MATERIALS AND METHODS}

\section{Sampling}

The samples were obtained from outer zones of the Cathedrals of Sala manca. Seville and Toledo (Spain) and Lund (Sweden), where green patina were apparent. The substrates where cyanobacteria and algae were growing included terracotta. sandstone. limestone. marble and granite. Samples were taken by scraping the substrate surface. Each sample was divided into subsamples for: (1) optical microscope observations; (2) inoculation of enrichment cultures and. if enough material was available. (3) for scanning electron microscope observations.

\section{Identification}

The identification of the cyanobacteria and/or algal component in the aggregates was achieved following the morphological characteristics of the taxa in the field samples as well as in enrichment and. if obtained, in monocyanobacterial and monoalgal cultures throughout the culture period.

\section{Culture methods}

The enrichment cultures were made in parafilm-sealed Petri dishes with BG1 1 (Rippka et al.. 1979) or BBM (Chantanachat \& Bold, 1962) solid 
medium. by placing small fragments of biomass-containing material on the agar surface. Cultures were kept at $20^{\circ} \mathrm{C}$ under a $12 / 12 \mathrm{~h} \mathrm{light/dark}$ cycle (light intensity of $800 \mathrm{~lx}$ ). The isolation procedure followed standard microbiological techniques.

Colonization of stone was also induced in the laboratory. The stone used was a white-yellowish calcarenite with coarse grain (up to $4 \mathrm{~mm}$ ) and high porosity (around $40 \%$ ). from Puerto de Santa Maria (Spain) quarry. This limestone has been widely used in cathedrals. churches and palaces in south-west Spain. Before inoculation. the cubic stone samples were conditioned during 1 week by immersion in distilled water. The final $\mathrm{pH}$ of the leaching water after conditioning was 8.7 . The stones were sterilized in an autoclave and aseptically introduced into sterile glass chambers containing liquid medium at the bottom. After 2 days, the stones were inoculated and the chamber sealed with parafilm in order to prevent evaporation. Two isolated strains were chosen for the culture of the cyanobacteria and algae on stone: Microcoleus vaginatus (strain SAL $3 \mathrm{H}$ ) and Klebsormidium flaccidum (strain TOL 2C-2). Unicya nobacterial and unialgal cultures were inoculated from the maintenance agar slants tubes into $250 \mathrm{ml}$ flasks containing $100 \mathrm{ml}$ of BBM liquid medium. The flasks were incubated in a rotary shaker at $25^{\circ} \mathrm{C}$ and under a light-dark cycle of $12 / 12 \mathrm{~h}$ (light intensity $400 \mathrm{~lx}$ ). After 2 weeks. $10 \mathrm{ml}$ aliquots of each culture were gently spread over the surface of the stones with a sterile glass pipette. The chlorophyll $a(\mathrm{chl} a)$ content of the cultures was measured. after extraction with methanol in the dark and at room temperature, by the absorption at $665 \mathrm{~nm}$ of the extracts (specific absorption coefficient after Mackinney, 1941). It was found to be $5 \mu \mathrm{g}$ chl $a \times \mathrm{ml}^{-1}$ for $M$. vaginatus and $14 \mu \mathrm{g} \mathrm{chl} a \times \mathrm{ml}^{-1}$ for $K$. flaccidum. The chambers were maintained at $25^{\circ} \mathrm{C}$. under a light/dark cycle (light intensity $250 \mathrm{~lx}$ ). After 2 months, the stones that showed visible growth were washed with distilled water. Several cycles of wetness-dessication were then applied, by placing the stones in an oven at $40^{\circ} \mathrm{C}$ and dropping distilled water each $12 \mathrm{~h}$. Samples for SEM observations were obtained by scraping stone surface.

\section{Electron microscopy}

For transmission and scanning electron microscopy, samples were treated following the methods described previously (Hernandez-Marine et al., 1991). Observation was made with a Phillips 200 transmission electron microscope and with a Hitachi-600 scanning electron microscope.

The taxa present in SEM micrographs were identified through 
similarities in size, shape. structure and habitat with those observed in corresponding field samples or in the cultures.

\section{RESULTS}

A total of 39 taxa have been identified. 15 of which are Cyanobacteria. 20 Chlorophyta. 1 Xanthophyta and 3 Bacillariophyta. The taxa list and the distribution are included in Table 1 . The filamentous cyanobacteria Microcoleus vaginatus and Phormidium autumnale and the chlorophyte Klebsormidium flaccidum (Figs $1-5$ ) were the most abundant taxa in the samples studied. comprising the majority of biomass as seen by optical and scanning electron microscopy.

The communities of cyanobacteria and algae rarely formed uniform green microbial films. localized at the surface of the material. The sampling was restricted to places with evident algal growth and was not designed to arrive at general conclusions on species distribution over the whole buildings. A general pattern of growth in place of constant water retention (cornices. holes. crevices and protected zones in general) was observed. In some cases a species segregation in very close sampling sites could be detected. For example. in Toledo Cathedral. Plectonema sp.. Chlorella homosphaera and Klebsormidium flaccidum were present on granite. and Nostoc sp.. Plectonema boryanum. Chlorella sp.. Chlorella reisiglii. Friedmannia israeliensis. Klebsormidium flaccidum. and Muriella terrestris on the adjacent mortar. In the Cathedral of Seville. the sampling carried out in summer was repeated in the same sites in winter. after a strong rainfall period. In spite of the intense algal proliferation observed in winter. the same range of species was present. only two new taxa appearing: Haematococcus pluvialis and Hantzschia amphyoxis.

In some places in Lund Cathedral, the mat formed by the algal growth was several millimetres thick. This mat, dominated by $K$. flaccidum, was located up to $50 \mathrm{~cm}$ from the ground and spontaneously detached. showing on its reverse side the presence of grains removed from the stone surface (Figs 6-8). SEM observations showed that it consisted of a mass of entangled algal filaments held in a slimy matrix, in which were embedded particles of different sizes coming from the stone (Fig. 13) and probably from the air. In the reverse side of the mat. the presence of fungal filaments together with dry. apparently dead algal filaments was observed.

Samples with less severe algal growth than that observed in the Cathedral of Lund also presented an intimate relation of filaments with the substrate, as observed in Seville Cathedral (Figs 9-12). SEM observation revealed that biomass was more abundant in flat sites or in 
List of Identified Taxa and their Distrithution in the Monuments Studied

$+B \quad C \quad D$

\section{CYANOBACTERIA}

Hyella sp.

Microcoleus vaginatus (Vauch.) Gom.

Myxosarcina concinna Printz.

Nostoc sp.

Nostoc punctiforms (Kutz.) Hariot

Oscillatoria amphigranulata Van Goor

Phormidium autumnale (Ag.) Gom.

Phomidium fragile' (Menegh.) Gom.

Phormidium subfuscum Kutz.

Phormidium temus (Menegh.) Gom.

Plectonema sp.

Plectonema honanum Gom.

P. borianum f. hollerbachiamum Elenk.

Symechocutis sp.

Tolypothrix byssoidea (Berk.) Kirchn.

$\begin{array}{lll}+ & + & + \\ + & & \\ + & & \\ + & & \\ + & + & + \\ & + & + \\ + & & + \\ & + & + \\ + & & + \\ + & & \\ + & & \end{array}$

\section{CHLOROPHYTA}

Apatococcus lobatus (Chod.) Boye-Pet

Bracteacoxcus ef minor (Chod.) Petrova

Chlorella sp.

Chlorella homosphaera (Skuja) Handa et Nakano

Chlorella reisiglii Wat.

Chlorella vulgaris Beij.

Chlorella zoofingensis Donz

Chloroky hus atmophyticus Geiller

Chlorosarcinopsix sp.

Ecdysichlamys obliqua G. S. West

Haemarococcus pluvialis Flotow

Friedmannia israeliensis Chantanachat et Bold

Klebsomidium flaccidum Silva. Mattox et Blackwell

Muriella terrestris Boye-Pet.

Neochloris bilobata Vinatz.

Pseudodendoclonium printzii (Vischer) Bourr.

Scenedermus quadricauda (Turp.) Breb. sensu Chod. +

Stichococcus hacillaris Naeg.

Trebouxia sp.

Trehouxia decolorans Ahmadjian

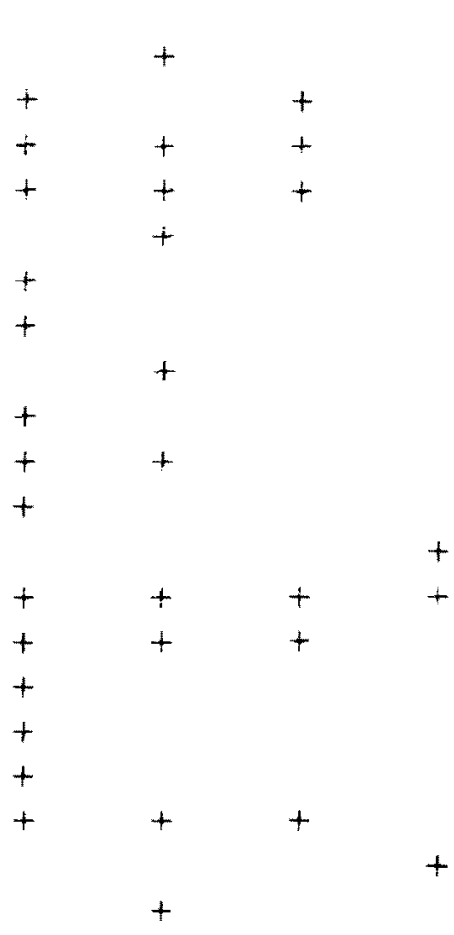

\section{XANTHOPHYTA}

Chlorellidium tetrahorn:s Vischer et Pascher

\section{BACILLARIOPHYTA}

Achnamtes coarctata (Breb.) Grun.

Hantzschia amphioxys (Ehr.) Grun.

Navicula mutica Kutz.

A: Pardon Gate. Cathedral of Sevilla: B: Cathedral of Salamanca: C: Cathedral of

Toledo: D: Cathedral of Lund. 


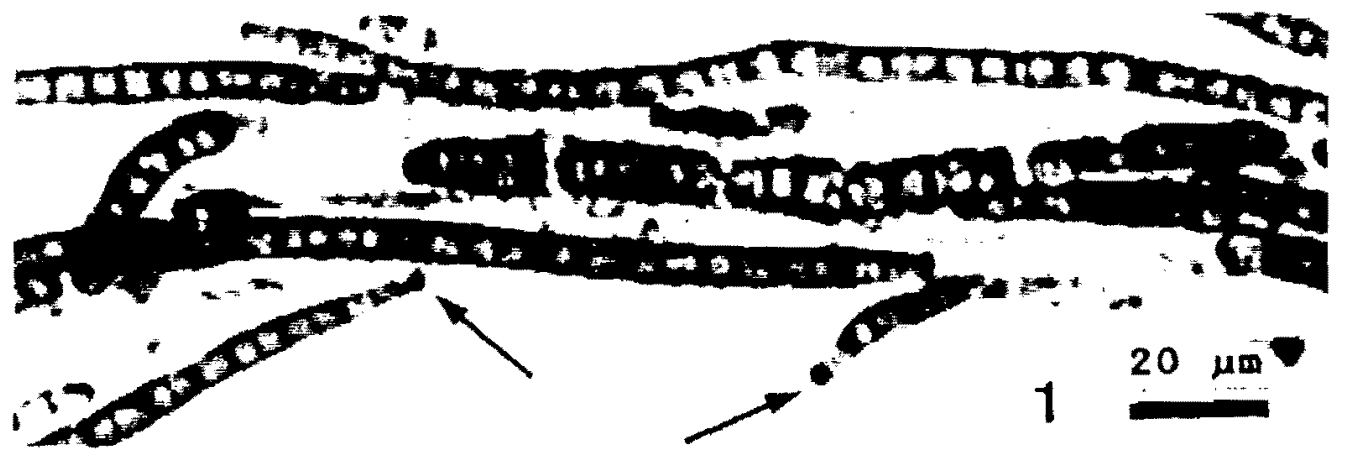

Fig. 1. Wicrocolems vaginatus, showing confuent sheaths and capitate end cells (arrows).

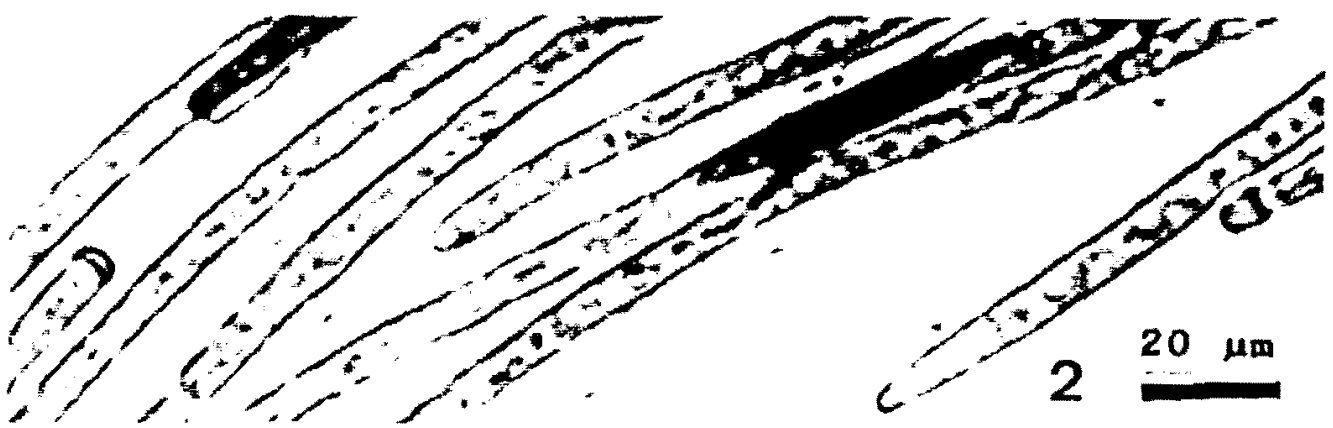

Fig. 2. Phormidium aumumnale.

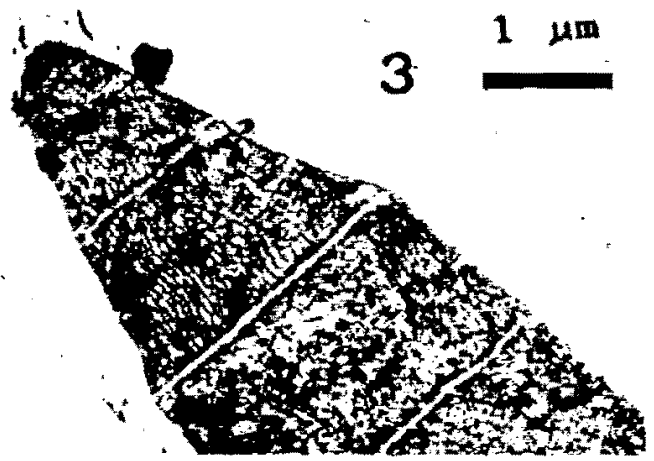

Fig. 3. Transmission electron micrograph (TEM) of a longitudinal section of Phormidium autumnalk, showing the general mophology, the individual sheath and the attenuated end cells. Irregular thylakoid arrangement with abundant phycohilisomes can be observed.

small. protected crevices. where the filaments penetrated following the fissures (Fig. 9). The filamentous cyanobacteria were found either alone (Figs 11 and 12) or with other taxa. forming a beginning of stratification. In this case. the upper layer was formed by cyanobacteria while, in 


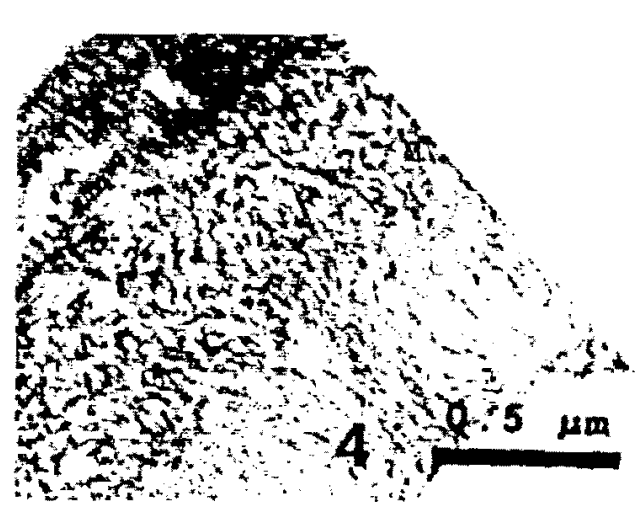

Fig. 4. TEM of the multilayered sheath of Phormidium autumnale In some cases. ats shown in the figure. the sheath reaches considerable thickness.

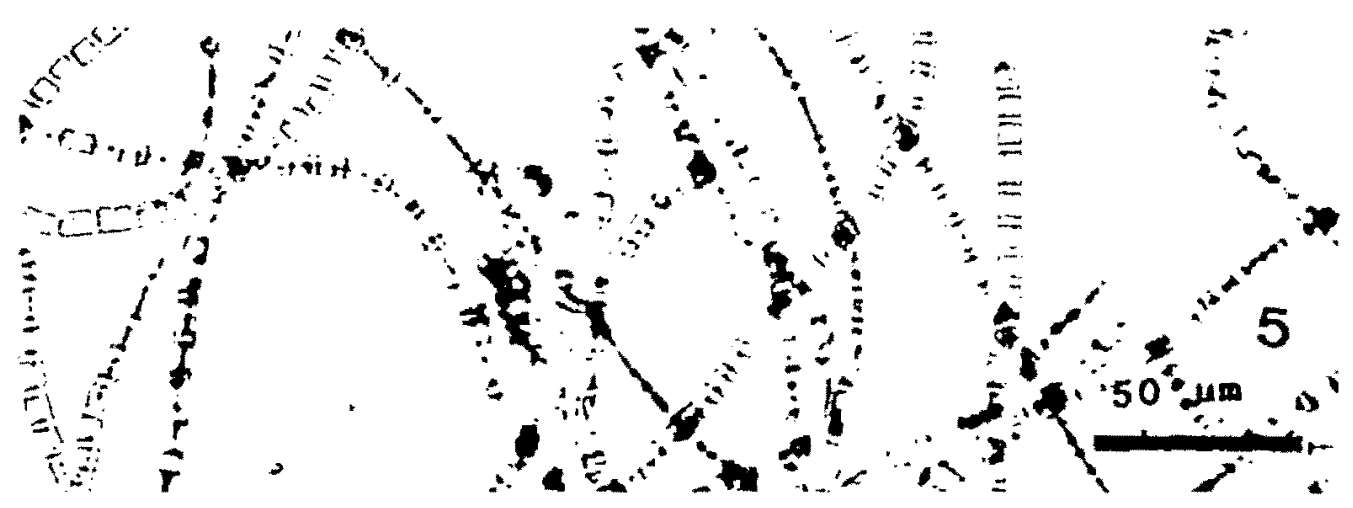

Fig. 5. Klehsormidium flaceidum from Cathedral of Lund.

general. K. flaccidum was in the layer helow. In sites with higher humidity or more protected against desiccation. $K$ flaccidum was found growing alone or with sarcinoid or coccoid algae. such as species of Chlorella and Muriella. In some humid places, association with fungi could also be observed.

Attachment of the filaments to the rigid surfaces. specially in the cyanobacteria. was mediated by the extracellular sheath material. clearly visible with optical and transmission electron microscopy (Figs 1-4). This material caused the close union observed in some samples. making it difficult sometimes to differentiate biological from non-biological structures. SEM showed that some cyanobacterial hormogonia. such as in the case of Phormidium autumnale, produced empty sheaths left behind in their movement (figure not shown).

Basically. the colonization induced in the laboratory under conditions of high humidity and nutrient abundance showed the same characteristics as the field samples (Figs 14-19). Clear differences in growth 


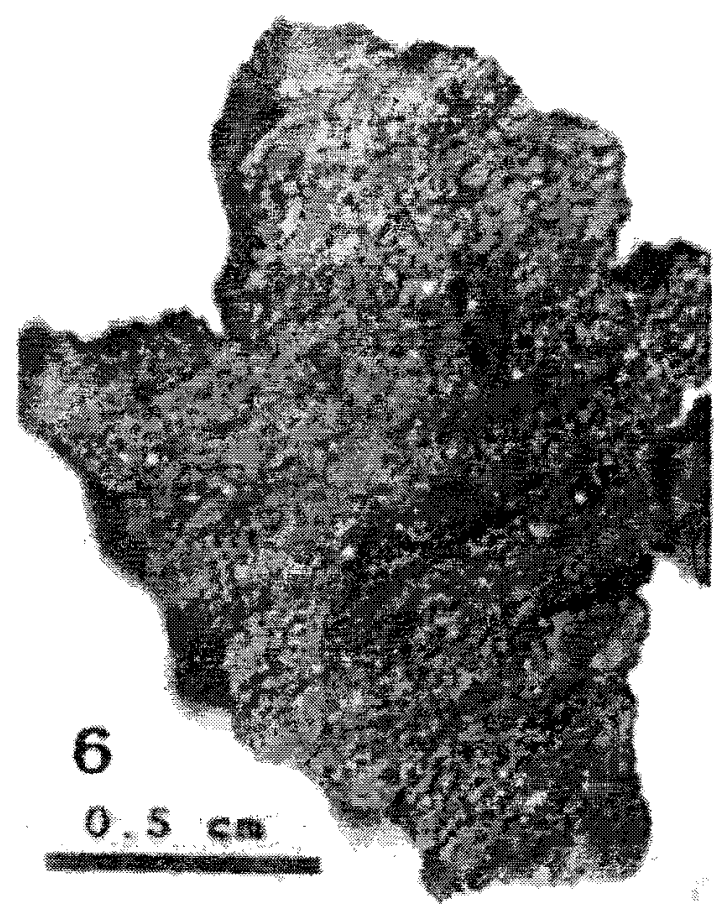

Fig. 6. Macrowcopic aspect of the outer late of an algal mat growing on sandstone from the Cathedral of Lund.

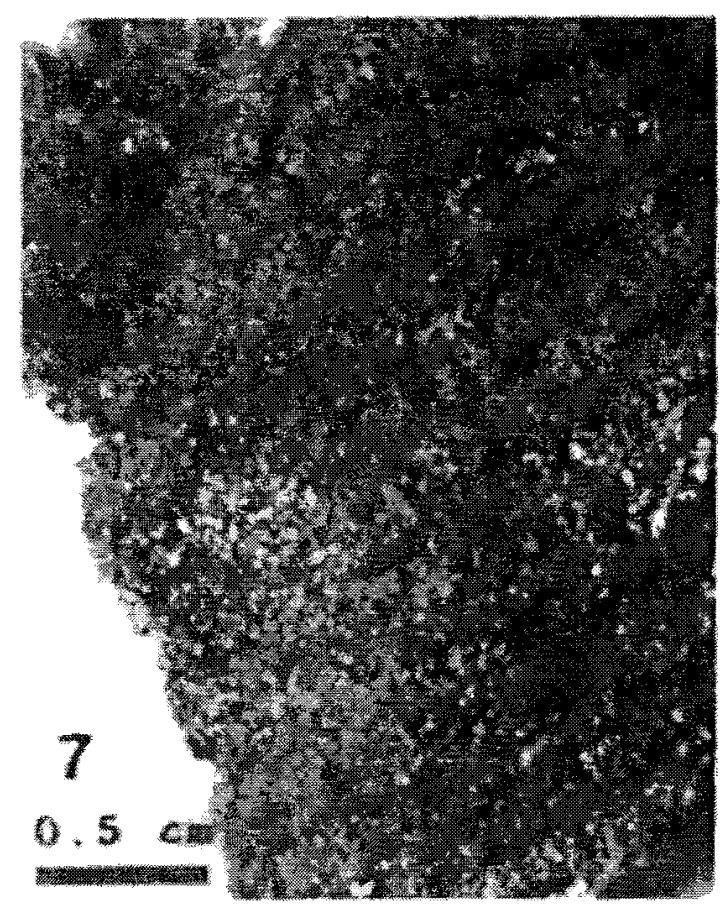

Fig. 7. The same as Fig. 6. hut of the reverse face. showing the stone grains attached to the mat. 


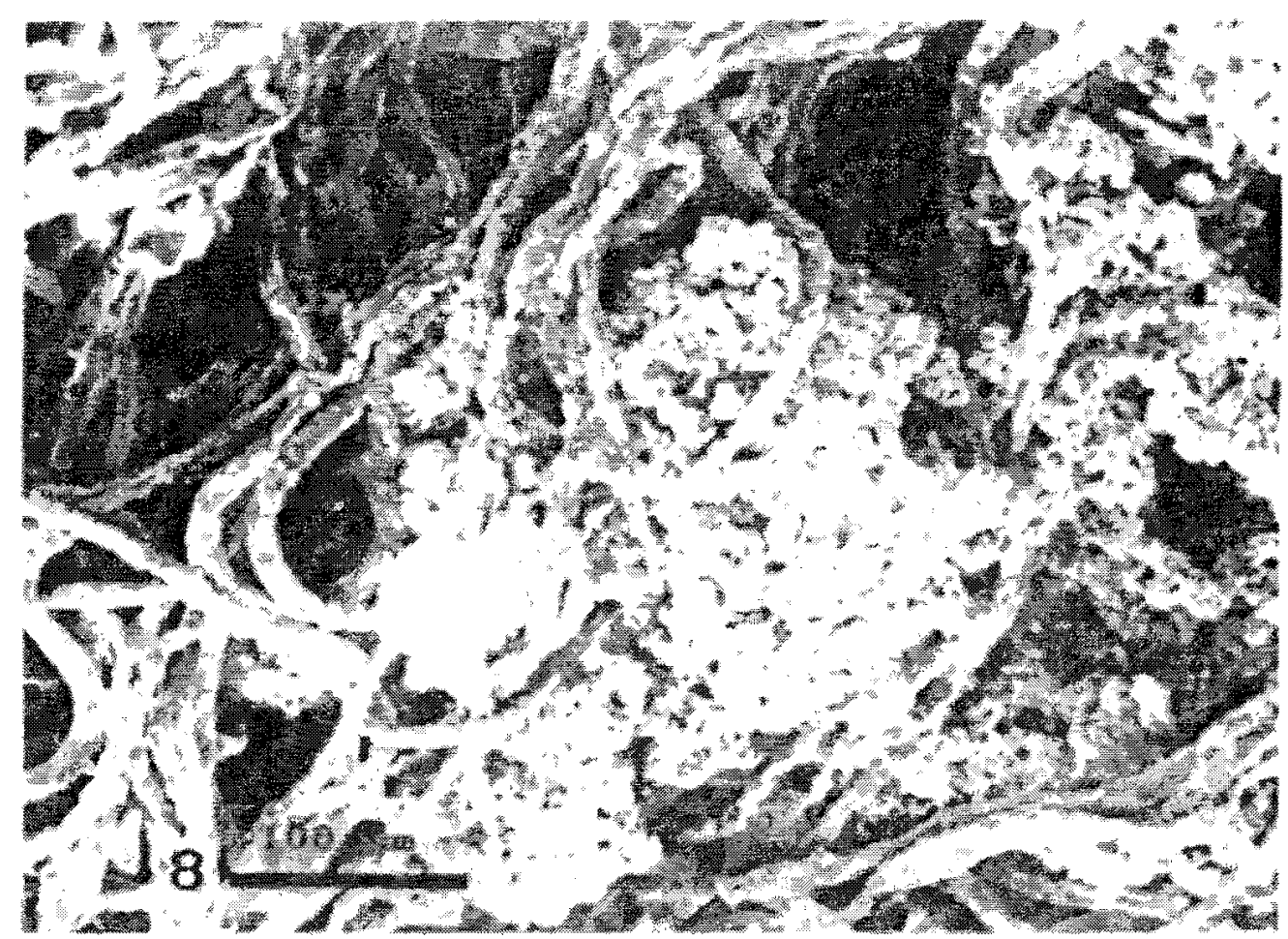

Fig. 8. Scanning electron micrograph (SEM) of the mat.

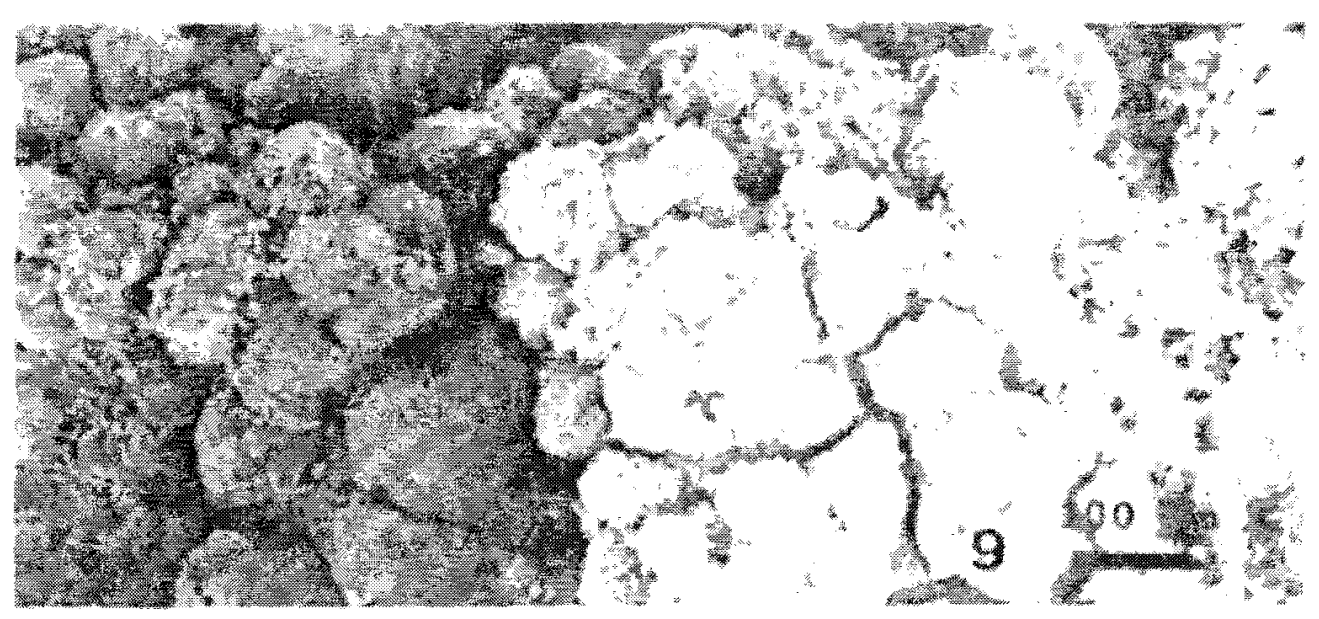

Fig. 9. SEM of the degraded surface of a terracota stutue from Pardon Gate. Cathedral of Seville. showing colonization within fissures.

pattern could be observed between the cyanobacterium and the green alga. Microcoleus vaginatus grew as a laver firmly hound to the stone surface by mucilage, which in some places was seen clearly cementing the stone grains (Figs 14 and 15 ). When stone preparations comprising the first few surface millimetres were observed upside-down. cyanobacterial trichomes could be observed. indicating their penetration in the 


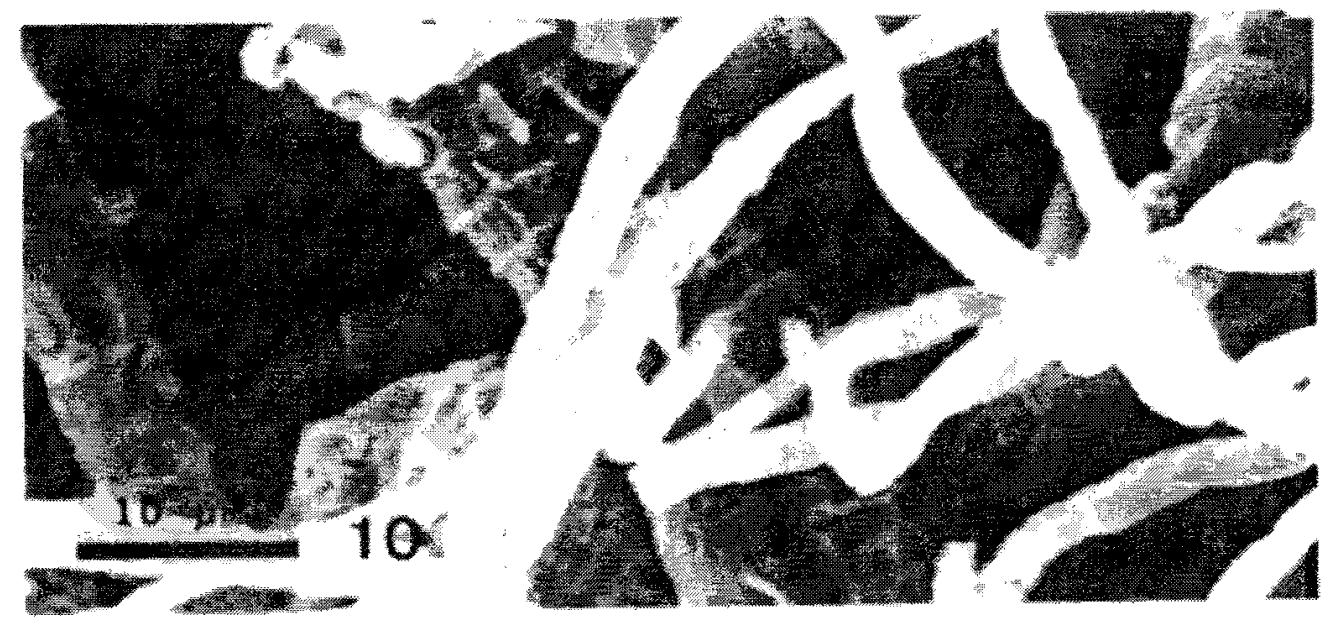

Fig. 10. SEM showing Klehwmidium flacidum growing under Phormidium aumumale.

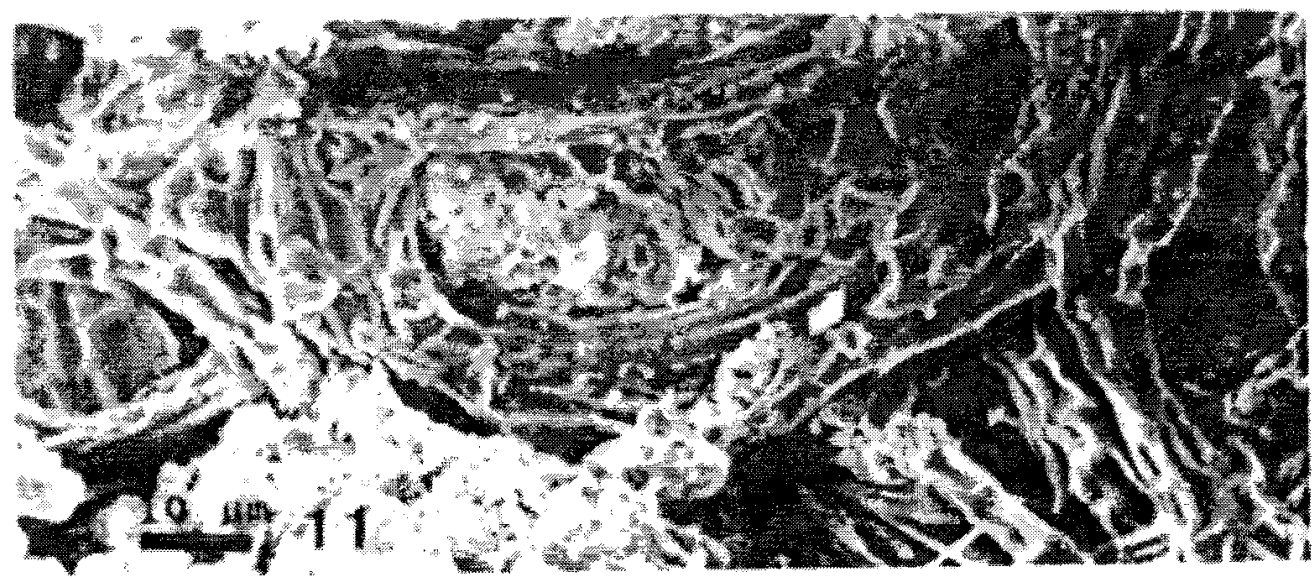

Fig. 11. Phormidium atatummale as seen by SEM.

stone allowed by the high porosity. These trichomes were interestingly devoid of sheaths (Fig. 16). In contrast. K. flaccidum grew forming a net of filaments over the stone surface. attached by specific points (Fig. 17). Also a slight penetration was observed from the inner face of stone preparations. The green alga showed a faster growth and a higher degree of stone colonization than the cyanobacterium under the growth conditions used. Cyanobacterial and algal aggregates could be detached easily from the stone surface. containing stone grains in clear analogy with the samples from the Cathedral of Lund (Fig. 18).

\section{DISCUSSION}

The range of species found in our study is similar to those observed in other studies on historic buildings and monuments (Raistrick \& Gilbert. 


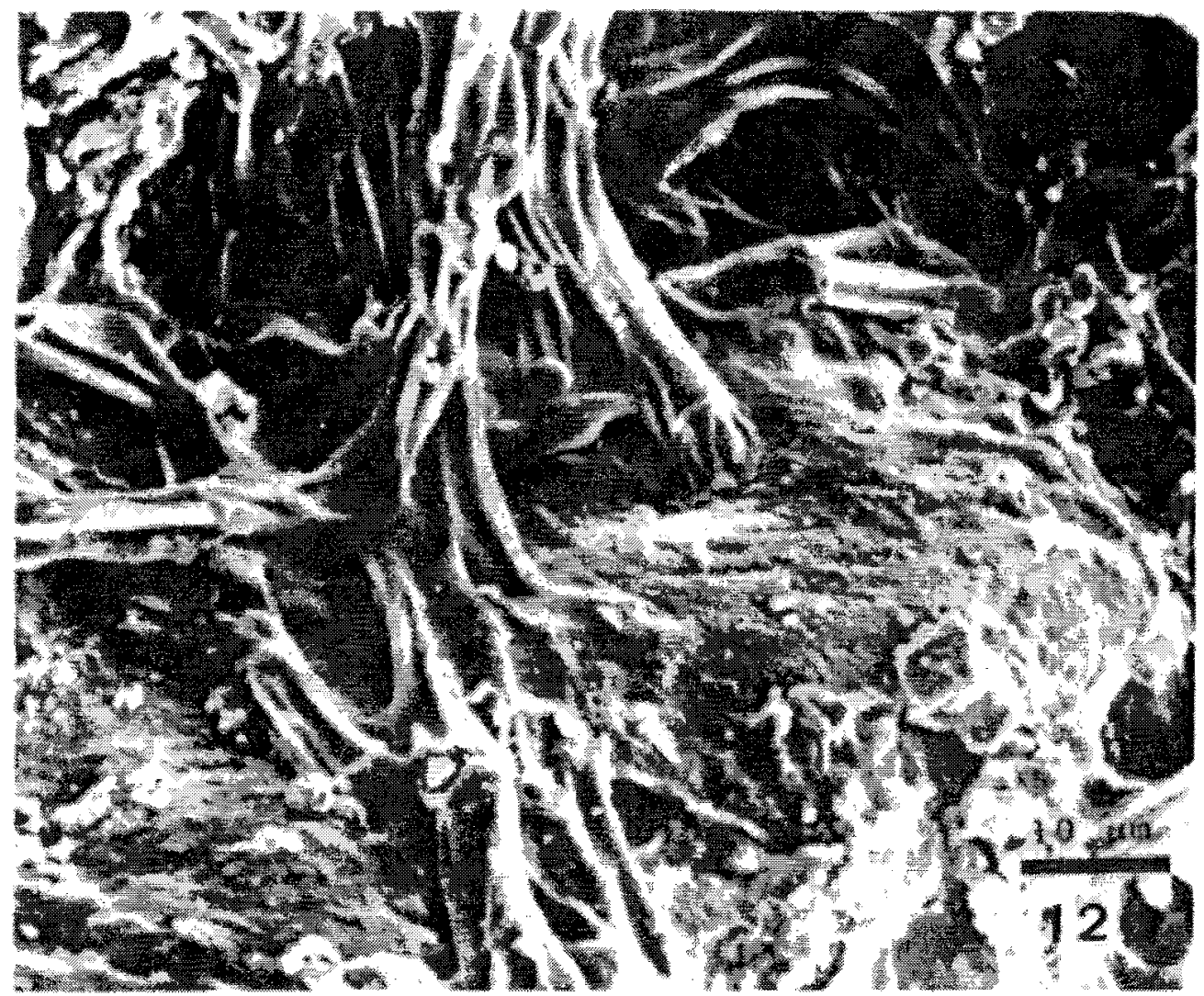

Fig. 12. SEM of cyanobacterial filaments growing intimately attached to stone surface through sheath material. in a sample from Pardon Gate. Cathedral of Seville.

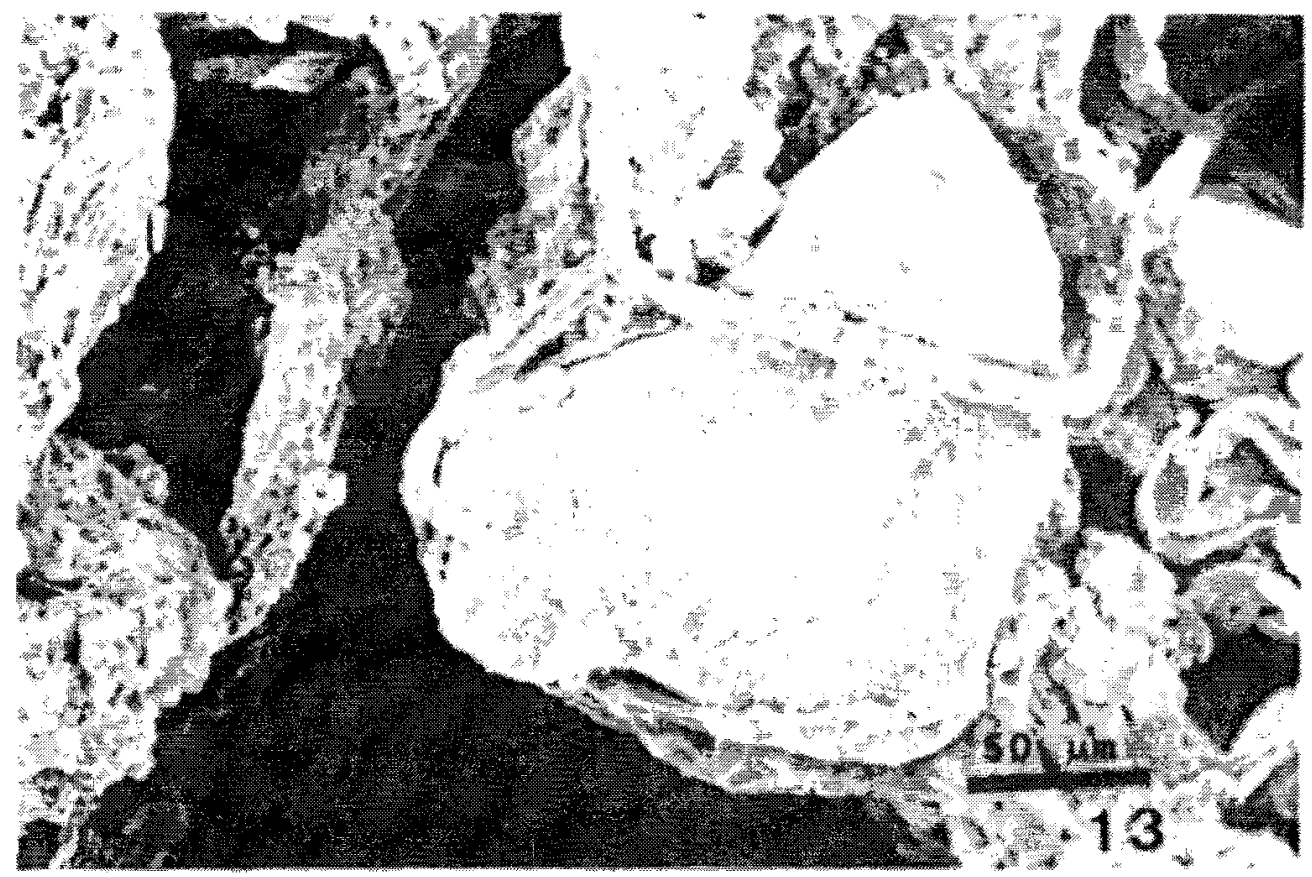

Fig. 13. SEM of stone grain held by Klehsormidium floccidum filaments on the reverse of the mat shown in Figs 6 and 7 . 


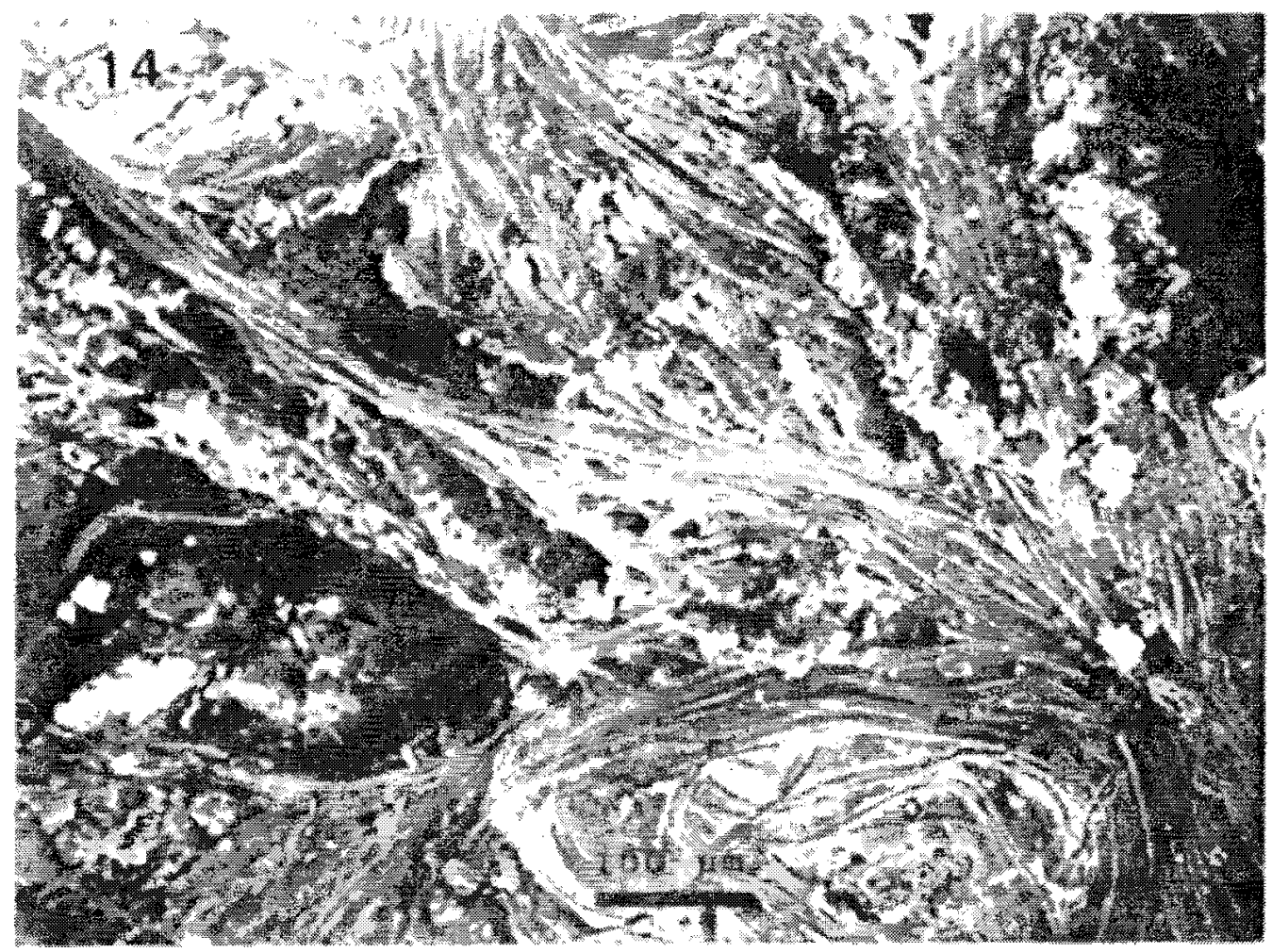

Fig. 14. SEM of Microcoleus laginatus growth pattern induced in the laborator:

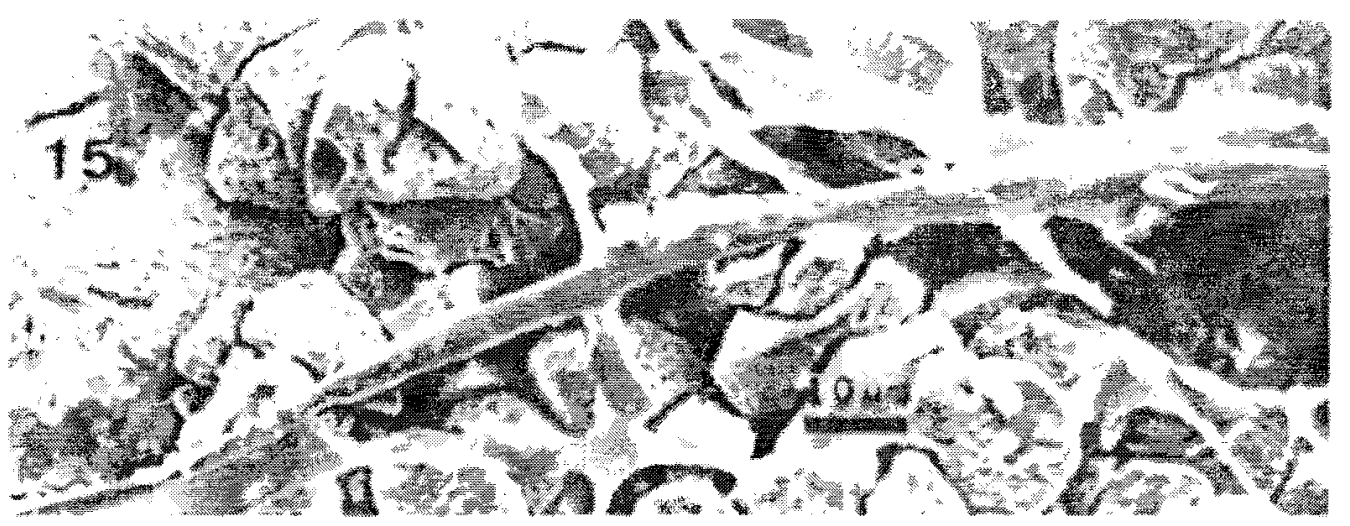

Fig. 15. Detail showing particle cementing by cyanobacterial sheath.

1963: Lefevre. 1974: Schlichting. 1975: Tomaselli et al., 1982: Anagnostidis et al., 1983: Rands et al.. 1984). With few exceptions. they are frequent in soils and corticolous habitats. not being characteristic in any particular region.

In our study only two heterocystous cyanobacteria. Nostoc sp. and Nostoc puncriforme. were found. The presence on the buildings of nitrogen-fixing cyanobacteria has heen considered as possibly relevant 


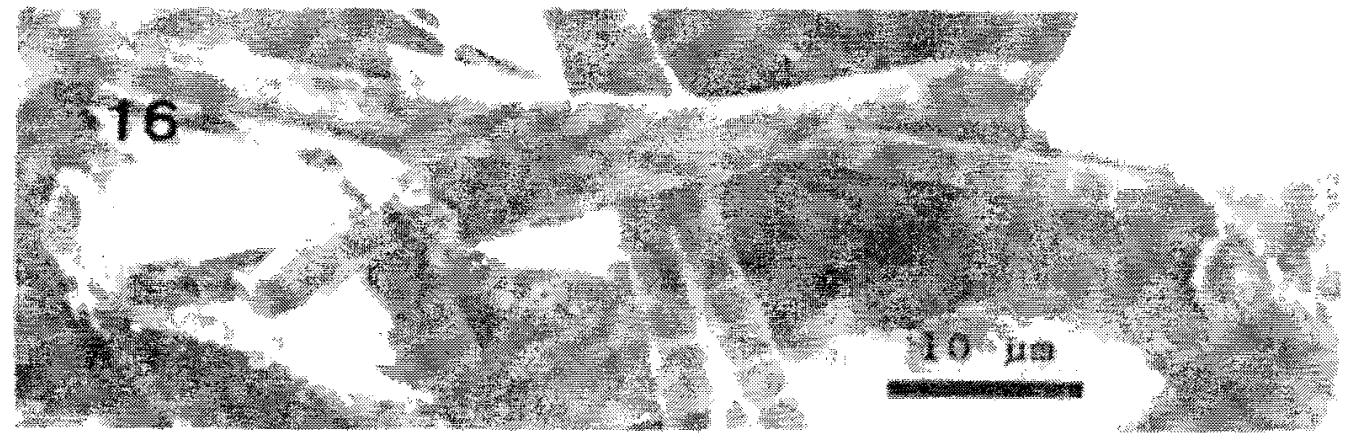

Fig. 16. SFM of Wierocolen vagmam trichomes growing inside the stone.

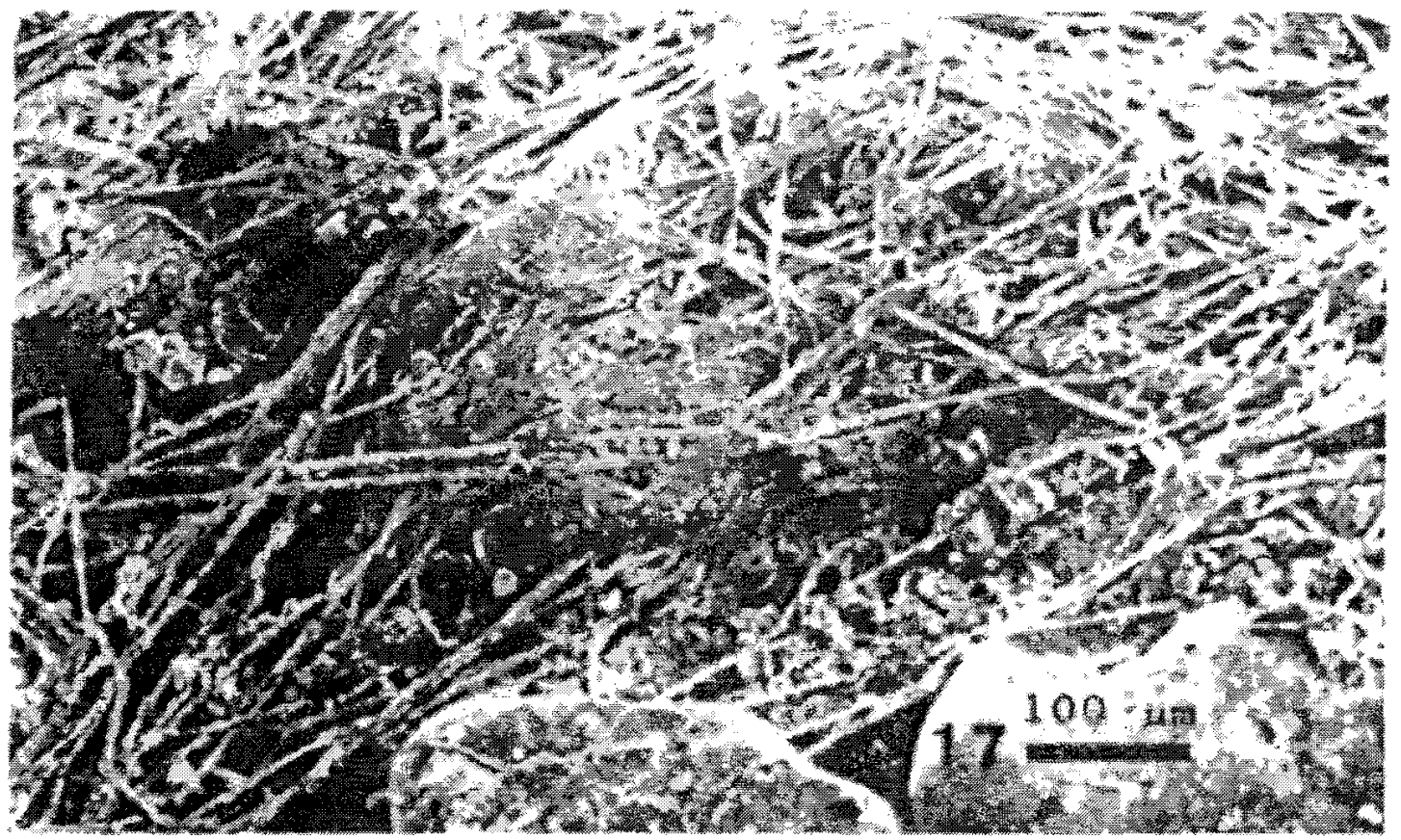

Fig. 17. SEM of Klobiormidium flaccilum growth pattern induced in the laboratory.

for the establishment and development of other organisms (Grant. 1982). although it is not clear whether in polluted environments the probable presence of combined nitrogen favours the presence of nitrogen fixers. Tomaselli et al. (1982) found abundance of species of Nostoc in samples from different wall paintings in Italy. The measured level of acetylene reduction (used to estimate the nitrogenase activity) was similar to that reported for Nostoc in another terrestrial environment (Whitton et al. 1979). In contrast. samples from stone monuments presented greater predominance of green algae (Tomaselli et al.. 1982).

The persistence of the species observed during the year in the Cathedral of Seville indicates their survival in drought periods even in the high temperatures reached in summer(up to $45^{\circ} \mathrm{C}$ ). An unfavourable 


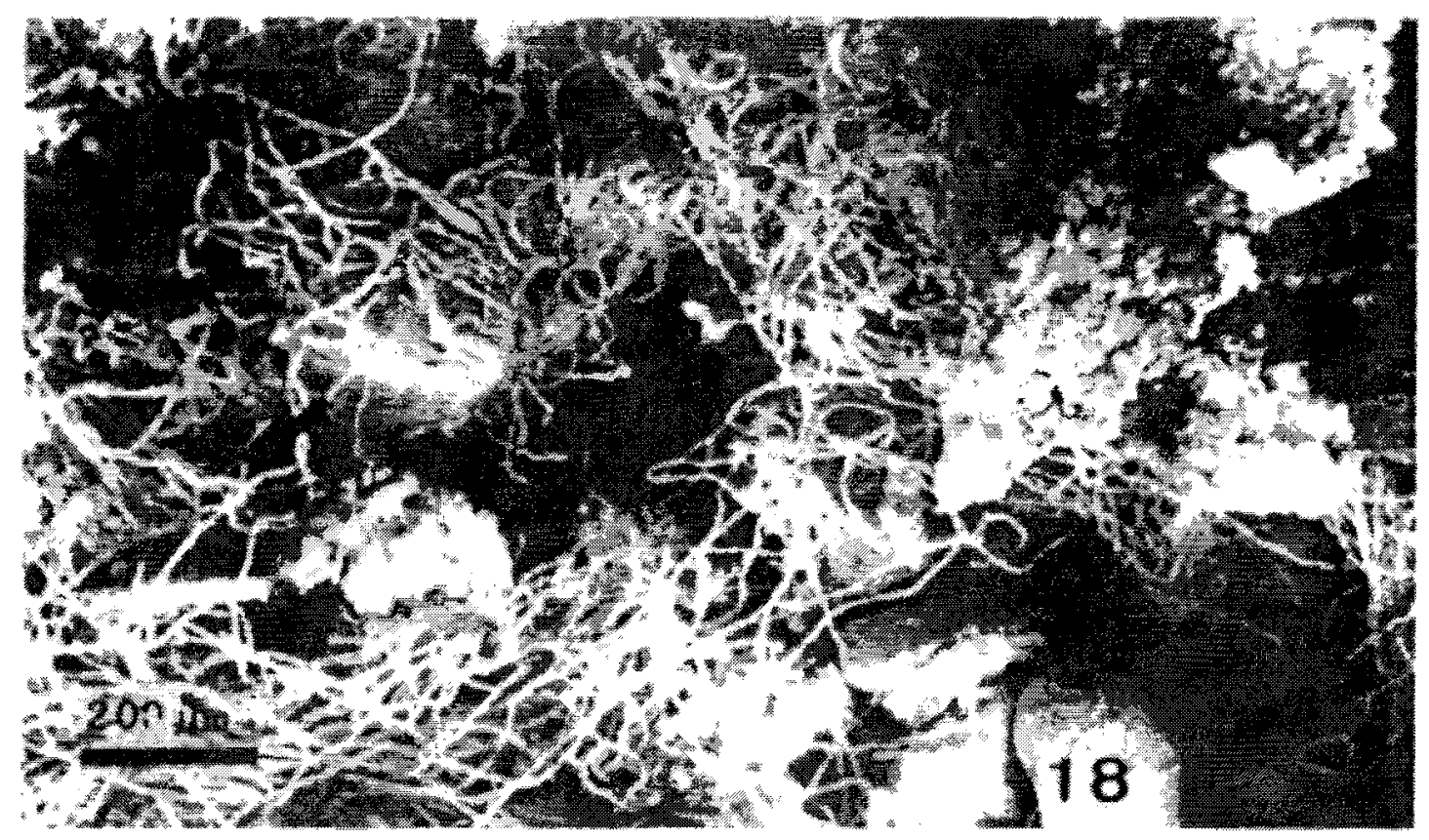

Fig. 18. SEM ol an algal aggregate detached from the cultured stone.

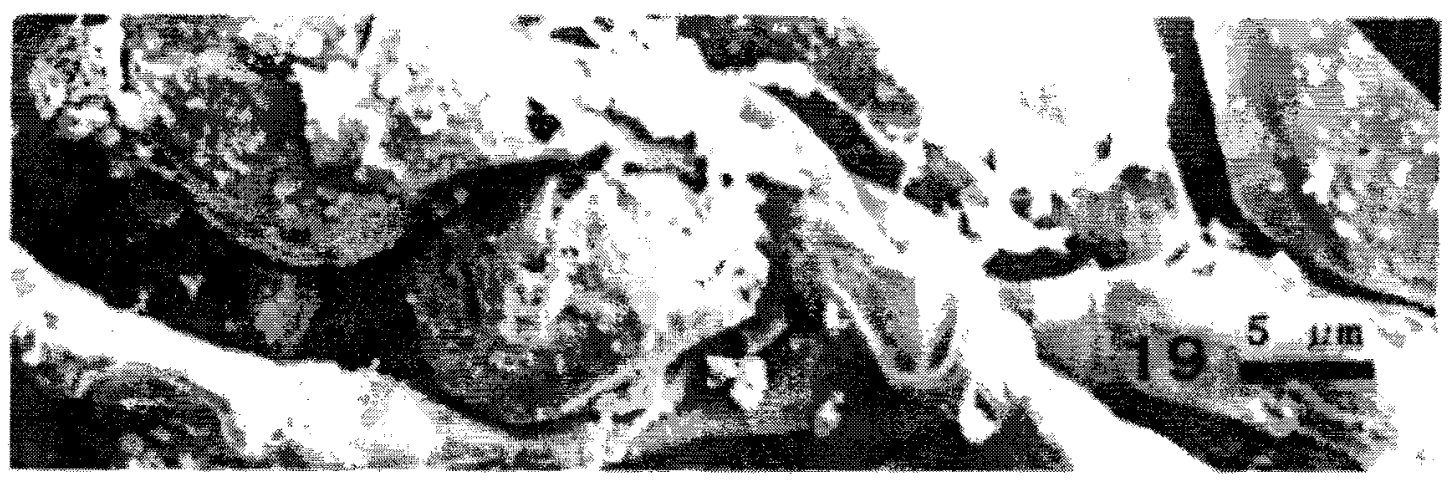

Fig. 19. Detail showing cohesion between particles and Klehsormidium flacidum filaments.

microclimate in the stone may induce the formation of resistant algal forms. This is a common mechanism in survival strategies (Mattox. 1971: Coleman. 1983). It was seen by Pietrini et al. (1985) in marble remains in Rome. The reddish-orange coloured patina present on the marble was produced mainly by the presence of cysts of Haematococcus pluvialis. which accumulated cytoplasmic carotenoids.

Most of the cyanobacteria identified and the filamentous chlorophyte $K$ flaccidum possess sheaths. The sheath in terrestrial cyanobacteria and algae acts as a reservoir of water. where it is bound through strong molecular forces (Campbell. 1979: Shephard. 1987). These organisms 
react to a scarcity of biologically available water by diminishing metabolic activity. Activity is quickly restored upon wetting (Potts \& Friedman. 1981). De Winder et al. (1989a) attributed part of the ability of metabolic activity recovery to the water retention properties of the substrate. Thus, the sheath contributes to their survival during drought periods (Trainor. 1985). In addition. a role of the sheath in substrate adhesion has been proposed (Robins et al. 1986). Furthermore. sheath production by the cyanobacteria and algae has been considered of importance for soil stability. acting as a cementing agent (Camphell. 1979: Starks et al.. 1981: De Winder et al.. 1989b). The empty sheaths produced by Microcoleus gliding movement was considered to be responsible for the increase in thickness of desert crusts (Camphell. 1979).

Due to its water retention properties. the sheath of cyanobacteria and algae undergoes large volume changes. collapsing when a critical amount of water is removed (Campbell, 1979). The volume changes of the sheath exert considerable force through repeated shrinking and relaxation when they are going through cycles of drying and moistening. loosening rock grains and constituting a possible factor in the gradual destruction of the rocks (Jaag. 1945: Friedmann. 1971: Golubic. 1973: Anagnostidis et al.. 1983). This may well be the cause of the mechanical degradation observed in our samples, which clearly showed the rock grains attached to the algal mats (Figs 6-8 and 13). The fact that this process is also effective in the case of less severe growth. was confirmed by laboratory experiences. involving the use of culture techniques.

The formation of crusts induced by cyanobacterial and algal growth also results in a longer moisture retention at the stone surface. increasing the mechanical damage produced by the freezing and thawing of water present in the pores of the stone (Hueck-van der Plas. 1968). A role in the calcium carbonate dissolution system, proposed for the weathering of rocks by epilithic cyanobacteria in nature (Viles, 1987). should not be discarded.

The association with fungi. detected by our SEM observations. may have relevance in the weathering of the stone. Cyanobacteria and algae may play an indirect role by supporting the growth of heterotrophic organisms such as fungi or bacteria, with higher destructive potential (Strzelczyk. 1981: Saiz-Jimenez, 1984; Koestler et al.. 1985: Andreoli et al.. 1988; Kuroczkin et al.. 1988: De la Torre et al.. 1991). In fact, the cyanobacteria and algae, when dead, become a nutrient source for heterotrophic microorganisms. Furthermore, heterotrophics can live at the expense of the extracellular organic matter synthesized by living cyanobacteria or algae (as in the case of bacteria thriving on the 
cyanobacterial sheath). If the biological layer is deep enough. the algae in contact with the stone surface lack enough light and die. becoming the substrate for the growth of fungi and bacteria at that level. where their chemically aggressive action through organic acid production can be more efficient. The water retention properties of the algal layer assures biological activity.

Combination of the observations in both field and laboratory materials may let us describe the process of colonization and development of cyanobacterial-algal communities on the stone. The filamentous cyanobacteria may well be the first colonizers due to their resistance to dessication provided by their developed sheaths. The mobility of their trichomes. as in the case of $M$. vaginatus. lets them spread over the surface: if the porosity of the substrate is high enough. the trichomes can even go inside the first few millimetres of the stone. where they can still live due to their low light requirements. The trichomes escape from their sheaths in their gliding movements. thus leaving empty sheaths that contribute to increased water retention properties of the stone surface. This makes the surface suitable for the colonization of the less droughtresistant algae such as $K$. flaccidum. It forms a surface network of filaments in which a more complex microbial community is developed. where heterotrophic organisms can degrade the organic material produced by primary productivity. The slimy surfaces of these communities favour the adherence of environmental particles (dust. pollen. spores. oil and coal-fired particles). The inclusion of these materials, together with those derived from the substrate (quartz. calcium carbonate. silicates) and detritus (dead cells. microbial byproducts. etc.). into the biogenic layer. gives rise to complex crusts and patinas.

\section{ACKNOWLEDGEMENT}

This research has been supported by the CEC through contract EV4V $0061 \mathrm{E}$ and CICYT (PAT89-0767-C04). Spain.

\section{REFERENCES}

Anagnostidis, K., Economou-Amilli, A. \& Roussomoustakaki. M. (1983). Epilithic and chasmolitic microflora (Cyanophyta. Bacillariophyta) from marbles of the Parthenon (Acropolis-Athens, Greece). Nova Hedwigia. 38, $227-87$.

Andreoli. C.. Rascio. N.. Garlet, L.. Leznicka. S. \& Strzelczyck, A. (1988). 
Interrelationships between algae and fungi overgrowing stoneworks in natural habitats. In Proceedings of the 6ith International Congress on Deterioration and Consenation of Stone. Supplement. ed. W. Domastowski.

Nicholas Copernicus University Press. Torun. pp. 324-27.

Campbell. S. E. (1979). Soil stabilization by a prokaryotic desert crust: implications for precambrian land hiota. Origins of Life. 9, 335-48.

Chantanachat. S. \& Bold. H. C. (1962). Phycological studies il. Some algae from arid soils. University of Texas Publication no. 6218. Austin, Texas.

Coleman. A. W. (1983). The roles of resting spores and akinetes in chlorophyte survival. In Survival Strategies of the Algae, ed. G. A. Fryxell. Cambridge University Press. Cambridge. pp. 1-22.

Danin. A. (1983). Weathering of limestone in Jerusalem by cyanobacteria. Zeitschrift fur Geomorphologie. Neue Folge. 27, 413-21.

Danin. A.. Gerson. R. \& Garty. J. (1983). Weathering patterns on hard limestone and dolomite by endolithic lichens and cyanobacteria: supporting evidence for eolian contribution to terra rossa soil. Soil Science. 136, 213-17.

De la Torre. M. A.. Gomez-Alarcon. G.. Melgarejo. P. \& Saiz-Jimenez. C. (1991). Fungi in weathered sandstone from Salamanca Cathedral. Spain. In The Science of the Total Environment (in press).

De Winder. B.. Matthijs. H.C.P.\& Mur. L. R. (1989a). The role of water retaining substrata on the photosynthetic response of three drought tolerant phototrophic microorganisms isolated from a terrestrial habitat. Archives of Microbiology. 152, 458-62.

De Winder. B.. Pluis. J.. De Reus. L. \& Mur. L. R. (1989h). Characterization of a cyanobacterial. algal crust in the coastal dunes of the Netherlands. In Microbial Mats. Physiological Ecology of Benthic Microbial Communities. ed. Y. Cohen \& E. Rosenberg. American Society for Microbiology. Washington. pp. $77-83$.

Dukes. W. H. (1972). Conservation of stone: causes of decay. Architects Journal. 156, 429-32.

Friedmann. E. I. (1971). Light and scanning electron microscopy of the endolithic desert algal habitat. Phycologia. 10, 411-28.

Giaccone. G.. Rinaldi. M. L. V. \& Giacobini, C. (1976). Forme biologiche delle alghe esistenti sulle sculture all'aperto. In The Conservation of Stone I. ed. R. Rossi-Manaressi. Centro per la Conservazione delle Sculture all Aperto. Bologna. pp. 245-56.

Golubic. S. (1973). The relationship between blue-green algae and carbonate deposits. In The Biology of Blue-Green Algae. ed. N. G. Carr \& B. A. Whitton. Blackwell Scientific Publications. London. pp. 434-72.

Grant. C. (1982). Fouling of terrestrial substrates by algae and implications for control - a review. International Biodeterioration Bulletin. 18, 57-65.

Hernandez-Marine. M.. Turon, X. \& Catalan. J. (1990). A marine Synechocystis (Chlorococcales. Cyanophyta) epizoic on didemnid ascidians from the Mediterranean Sea. Phycologia. 29, 275-84.

Hoffmann. L. (1989). Algae of terrestrial habitats. The Botanical Revien: 55, $77-105$.

Hueck-Van der Plas. E. H. (1968). The micro-biological deterioration of porous building materials. International Biodeterioration Bulletin. 4, 11-28.

Hyvert. G. (1973). Borobudur. les bas-reliefs materiaux-facteurs responsables 
des degradations- programme de conservation. Studies in Conservation. 18 , $131-55$.

Jaag. O. (1945). Untersuchungen uber die Vegetation und Biologie der Algen des nackten Gesteins in der Alpen. im Jura und im Schweizerischen Mittelland. Beitrage zur Kryptogamenflora der Schweiz, 9, 1-560.

Koestler. R. J.. Charola. A. E., Wypyski, M. \& Lee. J. J. (1985). Microbiologically induced deterioration of dolomitic and calcitic stone as viewed by scanning electron microscopy. In Proceedings of the 5th International Congress on Deterioration and Conservation of Stone. Vol. II. ed. G. Felix. Presses Polytechniques Romandes. Lausanne, pp. 617-26.

Kuroczkin. J.. Bode. K.. Petersen, K. \& Krumbein. W. E. (1988). Some physiological characteristics of fungi isolated from sandstones. In Proceedings of the tih International Congress on Deterioration and Consenation of Stone. Supplement, ed. W. Domastowski. Nicholas Copernicus University Press. Torun. pp. 2I-5.

Lefevre. M. (1974). La 'Maladie Verte' de Lascaux. Studies in Conservation, 19. 126-56.

Mackinney, G. (1941). Absorption of light by chlorophyll solutions. Joumal of Biological Chemistry. 140, 315-22.

Mattox. K. R. (1971). Zoosporogenesis and resistant cell formation in Hormidium flaccidum. In Contributions in Phycology, ed. B. S. Parker \& R. M. Brown. Jr. Kans Allen Press. Lawrence, pp. 137-44.

Metting. B.(1981). The systematic and ecology of soil algae. The Botanical Review: 47, 195-312.

Paleni. A. \& Curri.S. B. (1973). Laggression des algues et des lichens aux pierres et moyens pour la combattre. In Proceedings of the Ist International Symposium on the Deterioration of Building Stones, ed. V. Romanowski. Les Imprimeriès Reunies de Chambery. Chambery, pp. 157-66.

Pietrini. A. M., Ricci. S.. Bartolini. M. \& Giulani, M. R. (1985). A reddish colour alteration caused by algae on stoneworks. In Proceedings of the 5 th International Congress on Deterioration and Conservation of Stone. Vol. II. ed. G. Felix. Presses Polytechniques Romandes. Lausanne, pp. 653-63.

Pomar, L., Esteban. M.. Llimona. X. \& Fontarnau. R. (1975). Accion de liquenes. algas y hongos en la telodiagenesis de las rocas carbonatadas de la zona litoral prelitoral catala na. Instituto de Investigaciones Geologicas. Universidad de Barcelona, 30, 83-117.

Potts. M. \& Friedmann. E. I. (1981). Effects of water stress on cryptoendolithic cyanobacteria from hot desert rocks. Archives of Microbiology. 130, 267-71.

Raistrick. A. \& Gilbert. O. L. (1963). Malham Tarn House: Its building materials, their weathering and colonization by plants. Field Studies, 1, 89-115.

Rands, D. G.. Davis. J. S. \& Arana. L. R. (1984). Chemical and biological processes in coquina of Castillo de San Marcos National Monument. Schweizerische Zeitschrift fuer Hydrologie, 46, 109-16.

Rippka. R., Deruelles. J., Waterbury, J. B., Herdman, M. \& Stanier. R. G. (1979). Generic assignments, strain histories and properties of pure cultures of cyanobacteria. Journal of General Microbiology. 111, 1-61.

Robins. R. J.. Hall, D. O.. Shi, D. J., Turner. R. J. \& Rhodes, M. J. C. (1986). Mucilage acts to adhere cyanobacteria and cultured plant cells to biological and inert surfaces. FEMS Microbiology Letters, 34, 155-60. 
Saiz-Jimenez. C. (1984). Weathering and colonization of limestones in an urban environ ment. In Soil Biology and Consenvation of the Biosphere 2. ed. J. Szegi. Akademiai Kiado. Budapest. pp. 757-67.

Schlichting. H. E. Ir (1975). Some subaerial algae from Ireland. British Phycological Journal. 10, 257-61.

Shephard. K. L. (1987). Evaporation of water from the mucilage of a gelatinous algal community. British Phycological Journal. 22, 181-5.

Starks. T. L. \& Shubert. L. E. (1982). Colonization and succession of algae and soil-algal interactions associated with disturbed areas. Journal of Phycology: 18, 99-107.

Starks. T. L.. Shubert. L. E. \& Trainor. F. R. (1981). Ecology of soil algae: a review. Phycologia. 20, 65-80.

Strzelczyk. A. B. (1981). Stone. In Microhial Biodeterioration. ed. A. H. Rose. Academic Press. London. pp. 61-79.

Tiano. P. (1986). Biological deterioration of exposed works of ant made of stone. In The Biodeterioration of Constructional Materials. ed. L. H. G. Morton. Biodeterioration Society. Occasional Publication 3. Lancashire Polytechnic. UK. pp. 37-44.

Tomaselli. L.. Margheri. M. C. \& Florenzano. G. (1982). Indagine sperimentale sul ruolo dei cianobatteri e delle microalghe nel deterioramento di monumenti ed affreschi. In Proceedings of the 3rd International Congress on Deterioration and Preservation of Stones. Venice. Universita degli StudiIstituto di Chimica Industriale. Padova. pp. 313-25.

Trainor. F. R. (1985). Survival of algae in a desiccated soil: a 25 year study. Phycologia. 24, 79-82.

Viles. H. A. (1987). Blue-green algae and terrestrial limestone weathering on Aldabra atoll: An SEM and light microscope study. Earth Surface Processes and Landforms. 12, 319-30.

Whitton. B. A.. Donaldson. A. \& Potts. M. (1979). Nitrogen fixation by Nostoc colonies in terrestrial environments of Aldabra Atoll. Indian Ocean. Phycologia. 18, 278-87.

Q. In your abstract you state that ${ }^{\circ}$... the microbial films ... cause(d) a mechanical deterioration on the colonized materials." While the result is apparently true that filamentous microbes mechanically removed stone grains, it seems difficult to attribute this as the sole cause. Chemical deterioration. e.g. enzymatic or water dissolution. may be a contributing factor. (Your Fig. 15, from culture experiments. seems to show etched crystals.) What led you to attribute the deterioration to mechanical causes and not chemical?

A. In fact. there is some evidence of etched crystals in our limestone samples cultured in the laboratory. However. because the experimental procedure (cycles of wetness-dessication) could induce water dissolution of crystals, we cannot attribute it exclusively to microbial deterioration. On the other hand. we know. from culture observations. 
that the filaments contract when they are dry. If the cohesion between the filaments and the substrate is higher than the rupture resistance of the filaments. they will break down. In the case of growth on a substrate formed by particles. and the adherence of the substrate layers being lower than the traction tension created by the dry filaments. the grains will be progressively loosened.

Q. Is the sheath of the microorganisms reported here composed of sticky' molecules? If so this could certainly aid in mechanical degradation.

A. The adhesive properties of the extracellular sheath or mucilage produced by these organisms could be clearly observed by their tendency to adhere to the walls of the flasks where they were cultured. In fact. this material is responsible for soil stability by aggregating soil particles. However. chemical studies of extracellular mucilages of this type of organism are very rare. Flaibani et al. (1989) have identified two main components in this material: a polypeptide moiety and a complex glycuronoglycan. The hydrophilic proteinfree glycuronoglycans are not adhesive unless substituted with hydrophobic groups. The polypeptide moieties diminished the solubilities of the glycuronoglycans to which they were attached, and they contained $35-40 \%$ of hydrophobic aminoacid residues. Thus. these authors considered that the presence of hydrophobic polypeptide moieties played a major role in binding the hydrophilic glycuronoglycans to inert surfaces [Flaibani. A.. Olsen. Y. \& Painter. T. J. (1989). Polysaccharides in desert reclamation: compositions of exocellular proteoglycan complexes produced by filamentous bluegreen and unicellular green edaphic algae. Carbohydrate Research. $190,235-481$.

Q. If you were to try and remove or control the microbes on these stones would you target treatments to certain taxa? If so which?

A. In preliminary laboratory experiments we have observed that algae can use biocide formulations based on urea-derivatives as a nitrogen source. The algae Coccomyxa. Bracteacoccus and Klebsormidium grew better with very low doses of biocides (Diuron. Metabenzatiazuron and Simazine) than the controls. This means that. if the treatment is not repeated. these compounds may stimulate recolonization. when a favourable concentration is reached on the stone surface. Nevertheless. the response of different species to a given treatment may be different, as, for example, not all cya nobacteria a re capable of using urea as nitrogen source. Therefore the choice of appropriate treatments should be made after considering different factors, such as the specific response of the taxa to the treatment. the type of 
building material. etc. There are no universal treatments with optimal results in all cases. one of the reasons being the different responses of the taxa.

Q. Were you able to determine a rate of stone loss in your stone + microorganism culture experiments?

A. The systematic removal of microorganisms and loosened grains from the colonized stones is a rather difficult technical problem. if a certain degree of reproducibility is desired when estimating stone loss. We are currently working on standardization of the method. 